\title{
INVESTIGATION OF GLYCAEMIC INDICES OF BREAKFAST MEALS TYPICAL TO SRI LANKA
}

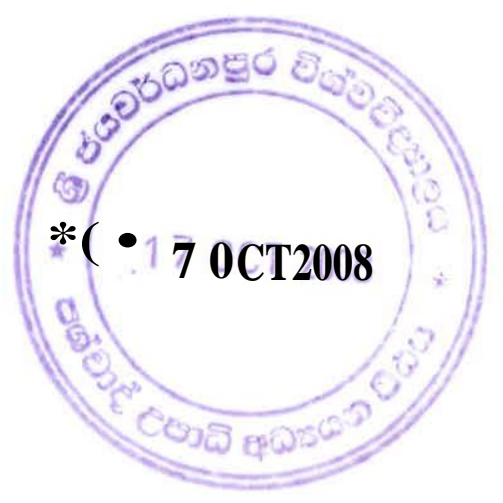

BO

\section{Rahal Dananja Widanagamage}

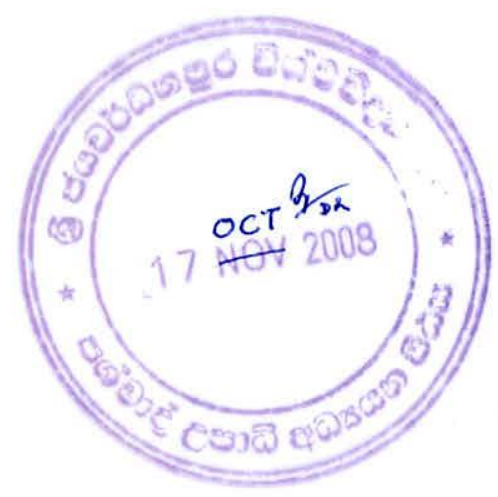

Thesiss submitued to the Umiversity of ShiiiJ Jayeaweandkemepura for the awardl of the Degree off Nhastter off Pthillosophy in Biochemistry in December 2007. 


\section{DECLARATION BY CANDIDATE}

The work described in this thesis was carried out by me under the supervision of Dr. S. Ekanayake (Department of Biochemistry, Faculty of Medical Sciences, University of Sri Jayewardenepura) and Prof. J. Welihinda (Department of Biochemistry, Faculty of Medicine, University of Colombo) and a report on this has not been submitted in whole or in part to any university or any other institution for another Degree/Diploma.

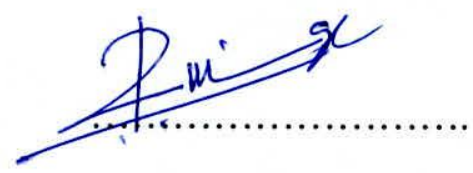

R. D. Widanagamage

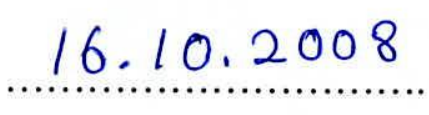

Date

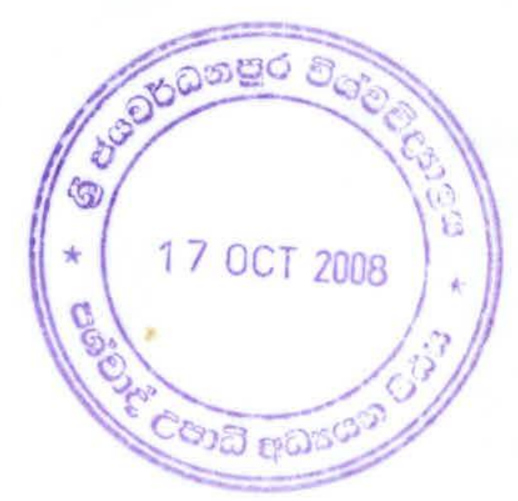




\section{DECLARATION BY SUPERVISORS}

We certify that the above statement made by the candidate is true and that this thesis is suitable for submission to the University for the purpose of evaluation.

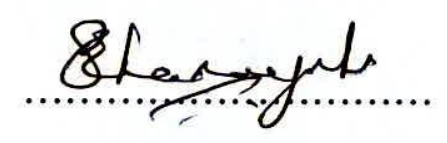

Dr. S. Ekanayake $16 / 10 / 08$

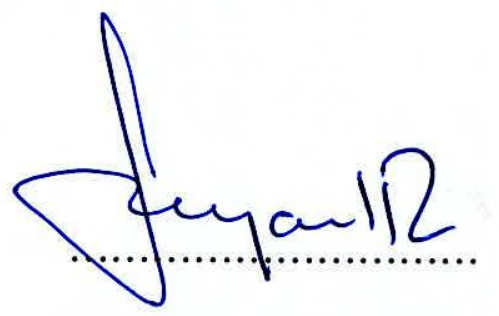

Prof. J. Welihinda

$16|10| 08$ 


\section{TABLE OF CONTENTS}

Page No.

LIST OF TABLES vii

LIST OF FIGURES viii

LIST OF PLATES ix

ABBREVIATIONS

ACKNOWLEDGEMENTS Xiv

$\begin{array}{lll}\text { ABSTRACT } & \text { xvi }\end{array}$

1. INTRODUCTION 1

2. LITERATURE REVIEW 6

2.1. Glycaemic Index 6

2.2. Methodological and other aspects related to GI 8

2.2.1. Number of subjects to be employed in a GI study 9

2.2.2. Number of times a reference food be given to a subject in a

GI study $\quad 9$

2.2.3. The physiological status of the volunteers 9

2.2.4. The type of reference food to be used in a GI study 10

2.2.5. Meal volume and consumption time recommended for a GI study 11

2.2.6. Nature of the carbohydrate to be used in a GI study 11

2.2.7. Amount of available carbohydrates to be given to a volunteer 11

2.2.8. Time of the day to perform the GI study 12

2.2.9. Effect of subject activities the day before the GI test day 12 
2.2.10. Blood sampling and sampling schedule to be employed in a GI study

2.3. Factors affecting the GI

2.3.1. Nutritional factors that affect GI

2.3.1.1.Effect of proteins on GI

2.3.1.2.Effect of fat on GI

2.3.1.3.Effect of dietary fibre on GI

2.3.2. Factors related to carbohydrate quality

2.3.2.1.Effect of botanical source on GI

2.3.2.2.Effect of the type of carbohydrate on GI

2.3.2.3.Effect of physical and chemical structure of starch on GI

2.3.3. Effect of different processing methods on GI

2.3.4. Effect of particle size on GI

2.3.5. Effect of acidity on GI

2.3.6. Effect of gastric emptying time on GI

2.3.7. Effect of satiety on GI

2.3.8. Effect of formation of resistant starch on GI

2.3.9. Effect of other factors on GI

2.3.10. Effect of chemical modification of foods on GI

2.3.11. Effect of second meal on GI

2.3.12. Collective effect of factors on GI

2.4. Glycaemic Index, health and disease 
$\begin{array}{ll}\text { 2.5.4. Olu-milk rice } & 35\end{array}$

$\begin{array}{ll}\text { 2.5.5. Breadfruit } & 35\end{array}$

2.5.6. Chickpea 36

$\begin{array}{ll}\text { 2.5.7. Mungbean } & 36\end{array}$

2.5.8. Cowpea 36

3. MATERIALS AND METHODS 37

$\begin{array}{ll}\text { 3.1. Materials } & 37\end{array}$

3.1.1. Raw materials for food preparation $\quad 37$

3.1.2. Water, chemicals and solvents 38

3.1.3. Collection of the blood samples from the volunteers 38

$\begin{array}{ll}\text { 3.2. Methods } & 38\end{array}$

3.2.1. Preparation of foods 38

$\begin{array}{ll}\text { 3.2.1.1.Roti } & 39\end{array}$

$\begin{array}{ll}\text { 3.2.1.2.Pittu } & 39\end{array}$

$\begin{array}{ll}\text { 3.2.1.3.Hoppers } & 40\end{array}$

$\begin{array}{ll}\text { 3.2.1.4.Chickpea } & 41\end{array}$

$\begin{array}{ll}\text { 3.2.1.5.Mungbean } & 41\end{array}$

$\begin{array}{ll}\text { 3.2.1.6.Cowpea } & 41\end{array}$

3.2.1.7.Milk-rice made with olu-rice $\quad 43$

3.2.1.8.Breadfruit $\quad 43$

3.2.2. Preparation of flour from foods 46 
$\begin{array}{ll}\text { 3.2.3.2.Ash content } & 47\end{array}$

$\begin{array}{ll}\text { 3.2.3.3.Digestible starch } & 47\end{array}$

3.2.3.4.Analysis of glucose concentration using Glucose-Oxidase kits 48

3.2.3.5.Standard curve of glucose using Glucose-Oxidase kit $\quad 49$

3.2.3.6.Total starch $\quad 49$

$\begin{array}{lr}\text { 3.2.3.7.Fat content } & 50\end{array}$

3.2.3.8.Dietary fibre content $\quad 51$

3.2.3.9.Protein content $\quad 53$

3.2.4. Determination of Glycaemic Indices 53

3.2.4.1.Volunteer preparation for the study 54

3.2.4.2.Meal portion size $\quad 54$

3.2.4.3.Ethical clearance and volunteer consent $\quad 54$

$\begin{array}{ll}\text { 3.2.4.4.Pilot study } & 54\end{array}$

3.2.4.5. Collection of blood samples and calculation of GI 55

3.2.5. Study of the parameters affecting GI 56

3.2.5.1.Effect of particle size on GI of roti 56

3.2.5.2. Water absorption index (WAI) and water solubility index (WSI) $\quad 56$

$\begin{array}{ll}\text { 3.2.5.3.Amylose content } & 57\end{array}$

3.2.5.4.Effect of extent of the gelatinization of starch granules on GI 58

3.2.5.5.Molecular size distribution of carbohydrates $\quad 59$

3.2.6. Statistical analysis $\quad 60$ 
4.1. Chemical composition of foods

4.1.1. Moisture, ash, protein, fat and energy contents of foods

4.1.2. Digestible starch, IDF, SDF and resistant starch contents of foods 61

4.2. Glycaemic Indices of foods

4.3. Palatability and meal sizes

4.4. Glycaemic Load (GL)

4.5. Fasting serum glucose concentrations, postprandial peak serum glucose concentrations and peak time

4.6. Glycaemic responses to foods

4.7. Studies of factors affecting the GI

4.7.1. Effect of dietary fibre, fat and protein

4.7.2. Particle effect

4.7.3. Effect from properties of starch

4.7.3.1.Amylose and amylopectin contents

4.7.3.2.Appearance of starch granules under the light microscope

4.7.3.3.Extent of swelling of starch granules in different foods 
ANNEXURE I List of communications from the thesis and manuscripts submitted

ANNEXURE II Proximate composition of different types of flour (in $100 \mathrm{~g}$ ) used in roti, pittu and hoppers preparations

ANNEXURE III Table 1. Proximate composition of coconut flesh and first extraction of coconut milk

ANNEXURE IV The questionnaire given to the volunteers who participated in the GI study

ANNEXURE V Ethical Approval from the Ethical Review Committee, Faculty of Medical Sciences, University of Sri Jayewardenepura

ANNEXURE VI Consent form given to the volunteers participated in the GI study

ANNEXURE VII Average incremental glycaemic responses to foods 


\section{LIST OF TABLES}

Page No.

Table 1.1 Typical Sri Lankan breakfast meals of which GI were determined 5

$\begin{array}{lll}\text { Table 2.1 Categories of GI } & 8\end{array}$

Table 3.1 Raw materials used for different roti preparations per person $\quad 39$

Table 3.2 Raw materials used for different pittu preparations per person $\quad 40$

Table 4.1 Moisture, ash, protein, fat and energy content of foods

expressed as fresh weight

Table 4.2 Digestible starch, IDF, SDF and resistant starch (RS)

of different foods expressed as fresh weight

Table 4.3 The IAUC, meal sizes, GI and GL of foods

Table 4.4 Palatability and meal sufficiency of the foods studied

Table 4.5 Fasting serum glucose concentration and peak serum

glucose concentration

Table 4.6 IAUC and peak serum glucose concentration for standard bread, normal wheat flour roti and ground wheat flour roti

Table 4.7 Amylose: amylopectin ratios, WAI and WSI of foods studied

Table 4.8 Distribution patterns of carbohydrates of different molecular weights in wheat flour roti, wheat flour pittu and chickpea in a sepharose gel column 


\section{LIST OF FIGURES}

Page No.

$\begin{array}{lll}\text { Figure 4.1 Standard curve for glucose } & 65\end{array}$

Figure 4.2 Average incremental glycaemic responses to wheat flour roti, wheat flour pittu and standard bread

Figure 4.3 Average incremental glycaemic responses to chickpea and standard bread

Figure 4.4 Average glycaemic response to breadfruit

Figure 4.5 Protein content of foods

Figure 4.6 Fat content of foods

$\begin{array}{lll}\text { Figure 4.7 IDF content of foods } & 76\end{array}$

$\begin{array}{lll}\text { Figure 4.8 SDF content of foods } & 76\end{array}$

Figure 4.9 Effect of protein concentration (g/ $100 \mathrm{~g}$ digestible starch containing meal) on the GI

Figure 4.10 Effect of IDF concentration (g/ $100 \mathrm{~g}$ digestible starch containing meal) on the GI

Figure 4.11 Effect of SDF concentration (g/ $100 \mathrm{~g}$ digestible starch containing meal) on the GI

Figure 4.12 Standard curve for amylose

Figure 4.13 Molecular size distribution of carbohydrates of wheat flour roti, wheat flour pittu and chickpea meal 


\section{LIST OF PLATES}

Page No.

Plate 3.1 Roti preparations (a) wheat flour roti (b) rice flour roti

(c) kurakkan flour roti (d) atta flour roti

Plate 3.2 Pittu preparations and miscellaneous foods (a) wheat flour pittu

(b) rice flour pittu (c) kurakkan flour pittu (d) hoppers

(e) olu-milk rice (d) breadfruit

Plate 3.3 Boiled legumes (a) chickpea (b) mungbean (c) cowpea

Plate 4.1 Light microscopic pictures of wheat starch granules stained with iodine in $\mathrm{KI}(10 \times 10)(\mathrm{a})$ raw wheat flour (b) wheat flour roti

(c) wheat flour pittu (d) standard bread

Plate 4.2 Light microscopic pictures of wheat and rice starch granules stained with iodine in $\mathrm{KI}(10 \times 10)(\mathrm{a})$ raw rice flour

(b) raw rice: wheat 1:1 ratio (c) rice flour roti (d) rice flour pittu

(e) hoppers

Plate 4.3 Light microscopic pictures of wheat and kurakkan starch granules stained with iodine in $\mathrm{KI}(10 \times 10)($ a) raw kurakkan flour

(b) raw wheat: kurakkan 2:3 ratio (c) kurakkan flour roti

(d) kuakkan flour pittu

Plate 4.4 Light microscopic pictures of starch granules of atta, olu-rice and breadfruit stained with iodine in $\mathrm{KI}(10 \times 10)(\mathrm{a})$ raw atta flour (b) atta flour roti (c) raw olu-rice (d) olu-milk rice

(e) raw bread fruit (f) boiled breadfruit 88 
Plate 4.5 Light microscopic pictures of legume starch granules stained with iodine in $\mathrm{KI}(10 \times 10)(\mathrm{a})$ raw chickpea $(\mathrm{b})$ boiled chickpea

(c) raw mungbean (d) boiled mungbean (e) raw cowpea

(f) boiled cowpea 


\section{ABBREVIATIONS}

AB-S

AB-T

ANOVA

AUC

AX

CHD

CV

CVD

$\mathrm{FF}_{\mathrm{M}}$

FM

$\mathrm{F}_{\mathrm{M}}$

FW

GI

GL

HDL

HMWC

IAUC

IDF

IGF

II

LDL

LMWC

MMWC
Absorbance of the standard glucose

Absorbance of the test sample

Analysis of Variance

Area Under Curve

Arabinoxylan

Coronary Heart Disease

Coefficient of Variance

Cardio Vascular Disease

Moisture of the fresh food

Fresh Weight

Moisture of the flour

Fresh Weight

Glycaemic Index

Glycaemic Load

High Density Lipoprotein

High Molecular Weight Carbohydrates

Incremental Area Under Curve

Insoluble Dietary Fibre

Insulin-like Growth Factor

Insulinaemic Index

Low Density Lipoprotein

Low Molecular Weight Carbohydrates

Medium Molecular Weight Carbohydrates 


\begin{tabular}{|c|c|}
\hline $\mathrm{N}_{1}$ & Normality of standard $\mathrm{HCl}$ \\
\hline NA & Not Applicable \\
\hline ND & Not Detected \\
\hline r.p.m. & Rounds per minute \\
\hline RAG & Rapidly Available Glucose \\
\hline RS & Resistant Starch \\
\hline SAG & Slowly Available Glucose \\
\hline SD & Standard Deviation \\
\hline SDF & Soluble Dietary Fibre \\
\hline SEM & Standard Error of the Mean \\
\hline SI & Satiety Index \\
\hline TDF & Total Dietary Fibre \\
\hline $\mathrm{V}$ & Nutrient value calculated from analysis of the flour sample \\
\hline $\mathrm{V}_{\mathrm{s}}$ & Total volume of the sample \\
\hline $\mathrm{W}$ & Sample weight in milligram \\
\hline $\mathrm{W}_{105}$ & Constant weight of the crucible with dried sample at $105^{\circ} \mathrm{C}$ \\
\hline $\mathrm{W}_{550}$ & Weight of the crucible with sample after incineration at $550^{\circ} \mathrm{C}$ \\
\hline WAI & Water Absorption Index \\
\hline $\mathrm{W}_{\mathrm{b}}$ & Constant weight of the beaker \\
\hline $\mathrm{W}_{\mathrm{c}}$ & Weight of the empty centrifuge tube \\
\hline $\mathrm{W}_{\mathrm{d}}$ & Dry weight of the sample \\
\hline $\mathrm{W}_{\mathrm{g}}$ & Weight of the centrifuge tube containing the gel \\
\hline $\mathrm{WHO} / \mathrm{FAO}$ & World Health Organization/ Food and Agriculture Organization \\
\hline $\mathrm{W}_{\mathrm{s}}$ & Constant weight of the beaker containing dried supernatant \\
\hline
\end{tabular}


$\mathrm{W}_{\text {sample }}$

WSI

$\mathrm{X}$

Y
Weight of the sample analyzed

Water Solubility Index

Volume of standard $\mathrm{HCl}$ used for the sample in $\mathrm{mL}$

Volume of standard $\mathrm{HCl}$ used for the blank 


\section{ACKNOWLEDGEMENT}

My knowledge relevant to this project started growing under the excellent supervision and periodical manoeuvring of my supervisor Dr. Sagarika Ekanayake (Department of Biochemistry, University of Sri Jayewardenepura). Had it not been for her commitment, guidance and contribution not only in experiments, but also in thesis and manuscript preparation, it would have been difficult for me to have completed my tasks within stipulated periods. Therefore I owe my supervisor Dr. Sagarika Ekanayake a deep debt of gratitude.

It is with great appreciation and gratitude that I acknowledge my supervisor Prof. Jayantha Welihinda (Department of Biochemistry, University of Colombo) for his supervision and directing me towards the achievement of goals of the project with invaluable suggestions, advices and comments in my thesis work and manuscript preparations.

My heartfelt gratitude goes to Prof. E.R. Jansz (Professor of Biochemistry, Department of Biochemistry, University of Sri Jayewardenepura) for providing the stipend (2006) from his grant (IPICS SRI: 07), some chemicals and allowing me to use the equipment as well as creating an enthusiastic research environment.

I am very much grateful to all the volunteers of the Faculty of Medical Sciences and the production staff of Camcol Polythene Pvt. Ltd (Malabe) who participated in the GI study dedicating time and the co-operation throughout the study in conducting my experiments.

The grants NSF/RG/2005/AG/10, IFS-E-3941/1 and NRC-05-03 are greatly acknowledged for the financial support including equipment, chemicals and my allowance. 
I wish to thank Dr. M.I.F.P. Jayewardene (Head of the Department in 2006) and Prof. H. Peiris (Head, Department of Biochemistry, University of Sri Jayewardenepura) for allowing me to work in the Department.

I am glad to acknowledge Dr. R. Wickremasinghe (Head, Department of Parasitology, University of Sri Jayewardenepura ) and the technical officers Mr. W.D.T. Tilakarathne and Ms. L.D.G.G. De Silva for the assistance given to me to carry out the light microscopic studies.

My thank goes to Dr. W.M.A.D.B. Wikramasinghe (Rice Research Institute, Batalagoda) for the assistance given to me in purchasing the AT 353 rice variety.

My thank goes to Ms A.S. Liyanarchchi (Camcol Polythene Pvt. Ltd.) who guided me in the meal preparation of volunteer diets and helping me to find dedicated volunteers.

My cordial thank goes to the laboratory colleagues Ms. A.M.B. Priyadarshani, Mr. Indika Senavitathna, Ms. Thushari Bandara and Mr. A.A.P. Keerthi for the assistance given to me throughout the study.

I also thank the academic and non academic staff of the Department of Biochemistry, University of Sri Jayewardenepura for helping me in many ways.

Last but not least I am very much grateful to my parents and brothers who always gave me a helping hand in many ways. 


\title{
INVESTIGATION OF GLYCAEMIC INDICES OF BREAKFAST
}

\section{MEALS TYPICAL TO SRI LANKA}

\section{Rahal Dananja Widanagamage}

\begin{abstract}
The Glycaemic Index (GI), which ranks foods according to their acute glycaemic impact is of immense use to dieticians in planning meals for patients seeking glycaemic control through dietary management. The GI values of typical Sri Lankan meals except for a few foods are not currently available. Hence the objective of this study was to determine the GI of selected breakfast meals typical to Sri Lanka and determine the factors responsible for the differences in GI.

The selected breakfast meals were roti made with wheat, rice, kurakkan and atta flour, pittu (wheat, rice and kurakkan), hoppers, boiled legumes (chickpea, mungbean and cowpea), olu-milk rice and boiled breadfruit. Roti and pittu preparations contained $50 \%$ coconut scrapings $(\mathrm{w} / \mathrm{w})$.

The proximate compositions (ash, protein, insoluble and soluble dietary fibre, fat, digestible and total starch) of the above food items were determined by standard methods.

The glycaemic indices were determined according to the WHO criteria with healthy volunteers ( $\mathrm{n}=10$, age 20-30 years). The volunteers were subjected to overnight fast and served the test foods and standard food/ Prima-crust top (containing $50 \mathrm{~g}$ or $25 \mathrm{~g}$ digestible starch). The GI values were calculated using the IAUC (Incremental Area Under Curve) of test and standard.
\end{abstract}


The light microscopic studies of isolated starch $(\times 100$ and $\times 400)$, effect of particle size, water solubility, amylose, amylopectin and water absorption indices of food flour and molecular size distribution of carbohydrates of selected foods (wheat flour roti, wheat flour pittu and chickpea) were studied in order to investigate the factors responsible for significant changes in GI.

The digestible carbohydrate content per $100 \mathrm{~g}$ fresh weight of the foods studied ranged from 9.3-41.8\%. The resistant starch content of kurakkan flour roti, chickpea and mungbean were $6.6 \%, 2.7 \%$ and $1.2 \%$ respectively. The IDF (insoluble dietary fibre), SDF (soluble dietary fibre), protein and fat content per $100 \mathrm{~g}$ fresh weight of cereal based foods, olu-milk rice and breadfruit ranged from 1.3 to $11.6 \%, 0.7$ to $3.1 \%$ and 0.5 to $22.3 \%$ respectively. The IDF, SDF, protein and fat contents per $100 \mathrm{~g}$ fresh weight of legumes were 6.6 to $8.2 \%, 1.9$ to $3.1 \%, 8.8$ to $10.8 \%$ and 0.9 to $3.0 \%$ respectively.

The boiled legumes (chickpea, mungbean and cowpea) were categorized as low GI foods and the GI ( \pm SEM) were $29 \pm 5,57 \pm 6$ and $49 \pm 8$ respectively. Wheat flour roti, rice flour roti, kurakkan flour roti, atta flour roti, kurakkan flour pittu and breadfruit were categorized as medium GI foods with corresponding GI values of $71 \pm 6,69 \pm 7$, $70 \pm 8,67 \pm 9,85 \pm 6$ and $64 \pm 7$ respectively. Hoppers, wheat flour pittu, rice flour pittu and olu-milk rice were classified as high GI foods and the GI ( \pm SEM) were $120 \pm 8$, $101 \pm 8,103 \pm 7$ and $91 \pm 8$ respectively.

The GI values of the foods studied significantly $(\mathrm{p}<0.01)$ and negatively correlated with the IDF $(\rho-0.780)$, SDF $(\rho-0.712)$ and protein $(\rho-0.738)$ contents in gram per $100 \mathrm{~g}$ digestible starch containing foods. 
The GI values of roti were significantly lower than that of pittu except for kurakkan flour pittu. This was irrespective of wheat flour roti and wheat flour pittu being made using the same composition of wheat flour and coconut scrapings. In order to explain this difference effect of processing on starch structure was studied.

According to light microscopic pictures, in roti where a dry cooking method has been employed the starch granules were swollen but intact. A significant $(\mathrm{p}<0.05)$ increase in length and breadth of wheat starch granules was observed in wheat flour pittu compared to wheat flour roti. The molecular size distribution patterns of carbohydrates of wheat flour roti and wheat flour pittu also indicated that wheat flour pittu to have a higher percentage of low molecular size carbohydrates compared to wheat flour roti. The other wet heat processed foods (hoppers, rice flour pittu, kurakkan flour pittu, olumilk rice and breadfruit) also had their starch granules disintegrated. According to the above observations the reason for the increase in GI of wet heat processed foods compared to dry heat processed foods could be mainly attributed to higher starch granular gelatinization/ disintegration. As revealed by gel filtration studies and light microscopic pictures gelatinized/ cell enclosed starch granular structure of boiled legumes could be partly responsible for the low GI of those foods. 